\title{
Analisis Kekerasan Seksual Pada Anak dan Intervensinya oleh Pekerjaan Sosial (Studi Kasus Kekerasan Seksual oleh Keluarga di Lampung)
}

\author{
Hetty Krisnani, Gisela Kessik, \\ Program Studi Kesejahteraan Sosial, Universitas Padjadjaran \\ Jl. Raya Sumedang KM 21, Jatinangor \\ Email: hettykrisnani@yahoo.com gisela16001.mail@unpad.ac.id ;
}

\begin{abstract}
Abstrak
Kekerasan terhadap anak sampai saat ini marak terjadi. Kekerasan seksual pada anak merupakan salah satu tindakan kekerasan yang cukup mengalami peningkatan. Berdasarkan berbagai data, pelaku kekerasan berasal dari keluarga terdekat yang dimiliki korban. Kasus Kekerasan seksual yang akan dibahas pada saat ini yaitu berkaitan dengan tindakan kekerasan seksual Incest yang dilakukan oleh Ayah, kakak, dan adik yang dapat kepada korban yang merupakan anak berusia 18 tahun. Pada bagian ini akan dibahas mengenai analisis motif, dampak, sampai pada intervensi yang dapat dilakukan oleh profesi pekerjaan sosial pada anak dan keluarga.
\end{abstract}

Kata Kunci: Kekerasan Seksual, Incest, Pekerjaan Sosial

\begin{abstract}
Violence against children until now is rampant. Sexual violence on children is one of the acts of violence which is quite increasing. Based on various data, the perpetrators of violence came from the closest family owned by the victim. Cases of sexual violence that will be discussed at this time are related to acts of sexual violence incest committed by fathers and siblings who get to victims who are children aged 18 years. This section will discuss the analysis of motives, impacts, and the interventions that can be carried out by the profession of social work in children and families.
\end{abstract}

Keywords: Sexual Violence, Incest, Social Work

\section{PENDAHULUAN}

Anak merupakan generasi penerus bangsa yang menjadi tumpuan di masa depan sehingga anak berdasarkan konvensi anak dan hukum yang berlaku telah memiliki hak-hak yang harus dilindungi. Berdasarkan UndangUndang No 4 Tahun 1979 pasal 1 ayat 2 tentang Kesejahteraan Anak dikemukakan bahwa: "Anak adalah seseorang yang belum mencapai umur 21 (dua puluh satu) tahun dan belum pernah kawin".

Meskipun demikian pada saat ini kekerasan pada salah satu anggota keluarga yaitu anak sampai saat ini masih sering terjadi. Berdasarkan UNICEF (dalam, Rusyidi \& Raharjo, 2018) jenis kekerasan yang dapat terjadi yaitu berbagai macam seperti kekerasan fisik, seksual, pengabaian, emosional dan eksploitasi. Kekerasan- kekerasan ini dapat dirasakan oleh anak di dalam keluarga. Kekerasan dapat terjadi pada anak laki-laki ataupun perempuan. Hasil pendataan Survei Pengalaman Hidup Perempuan Nasional (SPHPN) 2016, memperlihatkan bahwa 1 dari 3 perempuan usia 15 sampai 64 tahun mengalami kekerasan fisik atau seksual oleh pasangan atau bukan pasangannya selama hidup, dan sekitar 1 dari 10 perempuan usia 15 sampai 64 tahun mengalaminya dalam 12 bulan terakhir.

Kekerasan pada saat ini ternyata banyak dilakukan oleh orang-orang terdekat yaitu anggota keluarga. Data Komisi Perlindungan Anak Indonesia (KPAI) mencatat sebanyak 4.294 kasus kekerasan pada anak dilakukan oleh keluarga dan pengasuh (20112016). Kasus terbanyak terjadi pada 2013, yaitu 931 kasus namun sampai pada 2016 terjadi penurunan. Akan tetapi terdapat salah 
Focus: Jurnal

Pekerjaan Sosial

satu jenis kekerasan yang mengalami peningkatan yang cukup signifikan yaitu kekerasan seksual sehingga Komisi Nasional Perlindungan Anak (Komnas Anak) pada 2013 menetapkan status darurat nasional kekerasan seksual terhadap anak. Berdasarkan UNICEF (dalam Rakhmad, 2016), kekerasan seksual meliputi pelecehan seksual, penganiayaan, inses, perkosaan, kekerasan seksual, usaha perkosaan, pemaksaan seks, pemaksaan seks oral, sentuhan yang tidak pantas, pernikahan paksa, kekerasan dalam berkencan, kekerasan berbasis gender, kekerasan yang dilakukan pasangan intim, perkosaan sebagai sebuah tindakan perang, dan perkosaan dalam situasi konflik.

Catatan Tahunan Komnas Perempuan (2019) menyatakan tahun ini lembaga mitra atau penyelenggara layanan berbasis masyarakat dan UPPA Kepolisian mendokumentasikan sebanyak 89 kasus. Kekerasan seksual menjadi bentuk kekerasan yang paling menonjol menimpa perempuan dengan disabilitas, Pada kedua ranah bentuk kekerasan yang mendominasi adalah kekerasan seksual sebanyak 64\% (57 kasus) lalu kekerasan psikis sebanyak 20\% (18 kasus), kekerasan ekonomi sebanyak 9\% (8 kasus) dan kekerasan fisik sebanyak 7\% (6 kasus).

Kekerasan yang pada akhir-akhir ini mulai banyak muncul berkaitan dengan kekerasan seksual yang dilakukan anggota keluarga (incest). Berdasarkan catatan tahunan Komnas Perempuan (CATAHU) pada tahun 2019 untuk kekerasan seksual di ranah privat atau personal yaitu oleh anggota keluarga, incest atau kejahatan seksual yang dilakukan oleh orang dekat korban merupakan kasus yang paling banyak dilaporkan yakni sebanyak 1.071 kasus, sejumlah 103 kasus $(10 \%)$ dilaporkan ke polisi, dan masuk dalam proses pengadilan sebanyak 119 kasus (11\%). Di tahun ini, CATAHU juga menemukan bahwa pelaku kekerasan seksual tertinggi di ranah privat atau personal adalah pacar sebanyak 1.670 orang, diikuti ayah kandung sebanyak 365 orang, kemudian di peringkat ketiga adalah paman sebanyak 306 orang. Banyaknya pelaku ayah kandung dan paman selaras dengan meningkatnya kasus incest.

Incest merupakan suatu bentuk kejahatan dan pelanggaran terhadap HAM. Incest yang dilakukan oleh keluarga membuat kondisi keluarga yang seharusnya dapat memberikan perlindungan menjadi tidak berfungsi. Permasalahan ini dapat dilatarbelakangi oleh retaknya hubungan di keluarga, kurangnya moral pelaku, kondisi rumah yang tidak layak hingga adanya faktor kesempatan yang melatarbelakanginya (Tursilarini, 2016)

Pada kekerasan seksual ini korban merupakan pihak yang paling terhukum karena akan menganggu baik fisik maupun terlebih faktor psikis yang dimilikinya. Hasil penelitian Malamuth (dalam Tursilarini, 2016) menjelaskan bahwa kekerasan seksual dalam kaitannya tindakan perkosaan membuat Korban yang sebenarnya "terhukum" dalam artian yang paling dalam karena dirinya telah menjadi korban perbuatan yang mengakibatkan terenggutnya kehormatan yang selama ini dijaga sehingga akan menimbulkan gangguan mental dalam waktu yang berkepanjangan.

\section{Kasus Kekerasan Seksual Di Lampung}

Salah satu kasus Incest yang terjadi berada di daerah Lampung. Kasus ini menarik sorotan banyak kalangan dikarenakan kasusnya yang melibatkan pelaku yaitu ayah, kakak, dan adik kandung korban pada korban yang merupakan seorang penyandang keterbelakangan mental. Kekerasan seksual berupa incest yang terjadi di Lampung melibatkan hampir seluruh keluarga tersebut. Sesuai yang diberitakan oleh CNN Indonesia (25/2/2019), peristiwa ini melibatkan anak berinisial AG (18) yang merupakan korban yang memiliki 4 saudara dengan seorang ayah yang telah sendiri dikarenakan ibunya telah tiada. JM (44) merupakan ayah korban, kakaknya SA (24) dan YF (16) merupakan adik korban. AG sebenarnya memiliki saudara perempuan di dalam keluarga. Namun saudara perempuannya tidak terlibat dalam kasus ini dan tidak terbukti terlibat di dalamnya.

Kasus ini terkuak ketika Satgas Perlindungan Anak kala itu meminta izin kepada pihak keluarga untuk memberi pendampingan kepada AG yang diketahui mengalami keterbelakangan mental. Proses pendampingan yang mendatangkan psikolog untuk melakukan wawancara ternyata mampu menguak permasalahan yang menimpa korban. Selama ini dikarenakan keterbelakangan mental yang dimiliki AG yaitu pola pikirnya yang masih seperti anak-anak, Ia 
Focus: Jurnal

tidak merasakan ayah dan suadaranya telah melakukan kekerasan seksual terhadapnya.

Ketiga pelaku telah melakukan tindakan kekerasan tersebut puluhan sampai ratusan kali kepada korban. Berdasarkan penggalian informasi ketiga pelaku memiliki motif yang berbeda-beda. Ayah korban JM mengaku bahwa Ia menjadikan korban sebagai pelampiasan hasrat seksualnya karena telah lama tidak beristri dan tidak ada tempat untuk melampiaskan kebutuhan seksualnya serta kondisi anaknya yang disabilitas menjadi keuntungan olehnya untuk dimanfaatkan. Sedangkan pelaku yang merupakan kakak dan adik korban melakukan tindakan tersebut dilatarbelakangi oleh seringnya menonton film porno yang menjadi pemicu pelampiasan hasrat seksual kepada AG saudaranya.

Melalui penyelidikan ternyata diketahui selama ini SA sebagai kakak sering menonton film porno dan mengajak adiknya YF. Hal ini membuat SA dan YF menjadi kecanduan dan terpancing untuk melakukan tindakan kekerasan seksual kepada AG. Adiknya YF yang merupakan pelaku ternyata juga mengalami penyimpangan seksual. YF mengakui bahwa tidak hanya pada kakaknya Ia pernah melakukan tindakan kekerasan seksual namun Ia pernah melampiaskan hasrat seksualnya kepada objek binatang berupa sapi atau kambing milik tetangganya.

Perbuatan berani yang dilakukan kakak beradik ini juga tidak luput dari perbuatan yang dicontohkan oleh ayahnya JM. Sebagai orang tua JM bahkan membiarkan anak-anaknya ikut untuk melakukan perbuatan yang tidak terpuji tersbeut kepada salah satu anak perempuannya yaitu AG.

Kasus ini merupakan suatu ironi dimana keluarga yang seharusnya menjadi tempat yang paling aman dan memberikan kasih sayang tidak dapat melaksanakannya melainkan keluarga yang melanggar hak-hak anak. Melalui kasus ini tidak terlihat peran keluarga sebagai suatu sistem yang menumbuhkan nilai dan menjaga interaksi yang baik dalam lingkungan keluarga. Peran mendidik dan menerapkan nilai-nilai tidak terlaksana.

Kasus incest yang terjadi di Indonesia tidak hanya pada kasus AG di Lampung ini saja. Kasus yang sebelumnya pernah terjadi misalnya kasus yang terjadi di Samarinda dimana terdapat ayah yang melakukan kekerasan seksual kepada kedua anak perempuannya selama bertahun-tahun, ataupun ayah dan kakak laki-laki yang melakukan tindakan kekerasan seksual kepada korban yang merupakan anak dan adik dari sang kakak sampai korban mengalami kehamilan.

Banyaknya kasus kekerasan seksual yang terjadi dalam lingkungan keluarga ini menyiratkan adanya permasalahan di dalam sistem keluarga. Oleh karenanya dibutuhkan intervensi pada anak dan keluarga guna mengembalikan kembali keberfungsian sosialnya.

\section{PEMBAHASAN}

\section{Kekerasan Seksual oleh Keluarga Pada Anak}

\section{a. Kategori Kekerasan Seksual}

Kekerasan seksual dapat dilakukan oleh anggota keluarga ataupun orang diluar keluarga. Oleh karenanya, sering dilakukan pembedaan dalam dua kategori yaitu Familial abuse dan extra familial abuse (Noviana, 2015). Incest merupakan kasus dalam Familial abuse yang merupakan kekerasan seksual oleh pelaku yang memiliki hubungan darah dalam satu keluarga inti.

Mayer (dalam Noviana, 2015) menyebutkan incest dalam keluarga meliputi tindakan dalam beberapa kategori:

\section{a. Kategori pertama sexual molestation:}

Meliputi tindakan penganiayaan yang berkaitan untuk menstimulasi pelaku secara seksual, mencakup noncoitus, petting, fondling, exhibitionism, dan voyeurism.

b. Kategori kedua perkosaan atau sexual assault:

Mencakup tindakan oral atau hubungan dengan alat kelamin, masturbasi, stimulasi oral pada penis (fellatio), dan stimulasi oral pada klitoris (cunnilingus).

c. Kategori terakhir perkosaan secara paksa (forcible rape),

meliputi kontak seksual secara langsung yang mengandung pemaksaan.

Mayer (dalam Noviana, 2015) menyatakan bahwa dalam ketiga kategori tersebut, kedua kategori terakhir yang paling berat untuk mental korban. Rasa takut, kekerasan, dan 
Focus: Jurnal

Pekerjaan Sosial

ancaman menjadi sulit untuk dilupakan dan menganggu kejiwaan korban.

Pada kasus AG ini tergolong dalam kategori terakhir yang menyangkut kontak langsung. Meskipun AG tidak menyadari tindakan yang dilakukan oleh ayah dan saudaranya namun lambat laun peristiwa ini dapat membekas dan rawan bagi kejiwaan AG. Hal ini terlebih mengingat AG merupakan anak yang mengalami keterbelakangan mental dan berada di usia akhir anak yang tergolong memasuki tahapan krisis di dala perkembangannya.

Usia krisis ini sesuai yang diungkapkan oleh Erikson dalam teori perkembangannya. Dalam teori Erikson, AG memasuki tahapan identity vs role confusion (12-18 tahun). Teori Erikson ini berdasarkan (Krismawati, 2014) berusaha menjelaskan bahwa ada hubungan timbal balik antara pribadi dan kebudayaan sampai orang tersebut menjadi dewasa. Kebudayaan yang dimaksudkan adalah adanya pengaruh ekternal yang besar pada perkembangan diri individu. Hal ini berarti setiap individu mempunya kesanggupan untuk menyesuaikan diri dengan lingkungan yang senantiasa berkembang dari orang-orang atau institusi supaya Ia bisa menjadi bagian dari perhatian kebudayaan secara terus-menerus. Keberhasilan pada setiap tahapannya akan membawa individu pada pembentukan diri yang baik ataupun sebaliknya jika tidak terpenuhi akan didominasi pada kepribadian yang negatif.

\section{b. Penguat terjadinya Kekerasan Seksual pada Anak}

Kekerasan seksual yang terjadi pada AG merupakan perbuatan yang tidak biasa karena dilakukan oleh orang-orang terdekatnya yaitu ayah dan saudara-daudara korban. Kondisi mental AG yang masih seperti anak-anak membuat ayah AG menggunakan kesempatan melakukan tindak kekerasan.

Perilaku ayahnya kemudian diikuti oleh saudara laki-laki AG yaitu kakak dan adiknya. JM yang merupakan ayah AG memperlihatkan tindakan tidak terpujinya dan tidak melarang anak-anaknya untuk melakukan tindakan yang sama pada AG. Sistem nilai dan norma dalam keluarga ini tentu sudah tidak berfungsi sebagai pendidik yang baik. Namun melalui peristiwa ini maka dapat diamati bahwa terdapat interaksi dan reward yang baik didapat kakak dan adik oleh ayahnya. Perbuatan yang secara tidak langsung ditunjukan ayah dan diketahui oleh anak-anak laki-lakinya diikuti. Pada kasus ini ada perasaan reward yang dirasakan anak laki-lakinya sebab kedua anak tersebut merasa itu tindakan yang diperbolehkan oleh orang tuanya dan tidak dilarang.

Analisis ini berdasarkan pada teori Belajar Sosal oleh Albert Bandura. Pada teori dijelaskan bahwa seseorang di dalam perilakunya dipengaruhi tidak saja pada kognisi namun pada pembelajaran di lingkungannya. Anak melakukan pengamatan terlebih dahulu (observational learning) dan kemudian terdapat pengaruh kongnitif individu.

Proses mengamati yang terjadi ini berdasarkan Bandura terjadi berdasarkan beberapa tahapan yaitu (Prayogo, 2016):

\section{Atensi / Perhatian}

Anak di dalam keluarga tetap menetapkan sosok orang tua sebagai seorang role model di dalam hidupnya. Hal ini mengakibatkan anak memperhatikan perilaku yang dilakukan oleh orang tuanya. Dalam kasus ini kedua anak lakilaki JM memperhatikan perilaku yang dilakukan sehari-hari oleh JM.

\section{Retensi}

Di dalam proses ini, anak kemudian merekam peristiwa dan perilaku yang telah ditangkapnya. Peristiwa ini direpresentasikan secara simbolis di dalam ingatan.

\section{Reproduksi}

Setelah melihat dan merekam apa yang didapatkan kemudian anak akan mengubah hasil kognitif tersebut menjadi suatu tindakan. Hal ini berkaitan dengan tindakan kekerasan yang akhirnya dilakukan oleh kedua saudaranya pula kepada AG setelah sebelumnya ayahnya yang melakukan perbuatan tersebut.

\section{Penguatan dan Motivasi}

Berdasarkan tindakan yang telah dilakukan oleh seoarang anak, akan berlanjut pula pada feedback yang diinginkan oleh anak. Hal ini berkaitan juga pengaturan nilai yang didapatkan oleh anak. Jika tindakan anak tidak baik maka punishment atau hukuman yang 
Focus: Jurnal Pekerjaan Sosial
Hal: $198-207$

Desember 2019 akan didapatkan, namun jika perbuatan yang dilakukan oleh anak dinilai lingkungan baik maka akan diberikan reward atau penghargaan.

Pada kasus kekerasan seksual terhadap AG yang dilakukan khususnya oleh kedua saudara laki-lakinya, hal ini terjadi karena tidak adanya punishment yang didapatkan keduanya. Tindakan pembiaran yang dilakukan oleh JM sebagai seoarang ayah melihat perilaku kedua anaknya memberikan konsep bahwa tindakan yang telah dilakukannya tidak salah bahkan dapat diulangi kembali.

Faktor yang menjadikan penyebab SA dan YF melakukan tindakan ini juga dapat dianalisis berdasarkan peristiwa berbeda namun dalma satu teori yang sama yaitu berkaaitan dengan kegemaran keduanya dalam menonton video porno di dalam handphone sang kakak, SA. Pada peristiwa ini keduanya menangkap dan akhirnya merekam tindakan tersebut sebelum melakukan tindakan yang sama pada sang saudara AG. Bentuk pembiaran dan mengizinkannya sang kakak SA untuk YF ikut menonton video juga merupakan suatu feedback yang menjadikan YF berani melakukan tindakan kekerasan tersebut kepada sang kakak AG. Karena YF sebagai anak bungsu disini telah mendapatkan proses penguatan dan motivasi yaitu role model perilaku serta tidak adanya punishment dari kakaknya SA dan ayahnya JM.

\section{Pelanggaran Terhadap Hak Anak}

Anak dilindungi oleh hak-haknya yang berarti tindakan kekerasan seperti kekerasan seksual ini merupakan tindakan yang melanggar hak anak. WHO (dalam Infodatin Kementerian Kesehatan RI, 2014) menyataan bahwa batasan usia anak adalah sejak anak di dalam kandungan sampai usia 19 tahun. Hal ini seiring dengan yang disampaikan oleh Fedryansyah dkk (Fitri, Riana, \& Fedryansyah, 2015) bahwa hak anak adalah hak dasar yang wajib diberikan dan didapatkan oleh anak meliputi anak usia dini dan juga remaja usia 12-18 tahun. Hak ini merupakan hak yang dasar diberikan pada anak sehingga tumbuh kembang anak dapat berjalan baik. Hak-hak ini merupakan hak yang berlaku bagi seluruh anak secara universal pada semua negara yang meratifikasinya. Indonesia meratifikasi kedalam Kepres No 36 Tahun 1997 mengenai 10 Hak Mutlak Anak yang meliputi:
1. Hak Gembira :

Hak ini menyatakan bahwa setiap anak berhak atas rasa gembira dan hal ini harus terpenuhi untuk menunjang kesejahteraan anak

2. Hak Pendidikan :

Setiap anak memiliki hak untuk memperoleh pendidikan yang layak

3. Hak Perlindungan

Setiap anak berhak mendapatkan perlindungan, dilindungi dari segala tindak kekerasan dan penganiayaan.

4. Hak Untuk memperoleh Nama

Setiap Anak berhak memperoleh nama, sebagai salah satu identitas anak.

5. Hak atas Kebangsaan

Setiap anak berhak diakui sebagai warga negara dan memiliki kebangsaan, anak tidak boleh berstatus apatride (tanpa kebanngsaan).

6. Hak Makanan

Setiap anak berhak memperoleh makanan untuk tumbuh kembang dan mempertahankan hidupnya.

7. Hak Kesehatan

Setiap anak berhak memperoleh pelayanan kesehatan yang layak tanpa adanya diskriminasi. Anak harus dilayani dalam kesehatan. Hal ini penting karena anak merupakan generasi penerus masa depan bangsa.

8. Hak Rekreasi

Setiap anak berhak untuk rekreasi untuk refreshing. $\mathrm{Di}$ dalam menentukannya anak pun harus ikut dilibatkan dalam memilih tempat rekreasi yang mereka inginkan.

9. Hak Kesamaan

Setiap anak berhak diperlakukan sama dimanapun dan kapanpun, tanpa ada tindak diskriminasi.

10. Hak Peran dalam Pembangunan

Setiap anak berhak dilibatkan dalam pembangunan negara, karena anak adalah masa depan bangsa.

Sedangkan terdapat pula empat (4) hak dasar yang wajib dimiliki oleh anak yaitu:

\section{Hak Hidup}

Hak hidup ini berlaku dari semenjak anak itu masih dalam kandungan, yang termasuk kedalam hak hidup adalah seperti memberikan gizi dan rangsangan-rangsangan ketika anak 
Focus: Jurnal

masih dalam kandungan, periksa kandungan, dan lain- lain.

2. Hak Tumbuh Kembang Dalam kehidupan anak,

anak harus diberikan kesempatan sebaik-baiknya untuk tumbuh dan berkembang, seperti mendapatan pengasuhan, pendidikan yang baik, jika sakit diobati atau dibawa kedokter, diberi ASI,di imunisasi, dibawa ke posyandu.Selain itu perkembangan Psikisnya pun diperhatikan, seperti memberikan rasa aman dan rasa nyaman, membuat lingkungan kondusif, menjauhkan anak dari hal-hal yang berbahaya, tidak memberikan makanan yang berbahaya bagi perkembangannya.

3. Hak Partisipasi

Maksud dari hak partisipasi disini adalah anak harus dilindungi dari situasi-situasi darurat, menerapkan tentang perlindungan hukum, dan dari apapun yang berkaitan dengan masa depan si anak.

4. Hak Perlindungan

Anak mempunyai hak untuk mendapatkan perlindungan dan menentukan pilihan untuk hidupnya.Anak dalam keluarga harus dibiasakan berbicara, agar anak mempunyai hak suara dan mulai berani menentukan hal-hal yang diinginkan (Fitri, Riana, \& Fedryansyah, 2015)

Melalui hak yang telah diratifikasi oleh berbagai negara termasuk Indonesia ini, anak secara hukum nasional dan internasional telah memiliki hak dasar yang harus didapatkan. Hak-hak ini menjadi bagian penting untuk mencapai kesejahteraan dalam diri seorang anak sehingga pelanggaran terhadap hak-hak ini dapat menimbulkan permasalahan atau disfungsi pada keberfungsian anak di masa depannya.

Oleh karena itu, hak anak harus ditegakan dan diberikan pada diri setiap anak. Pelanggaran terhadap hak anak akan menimbulkan hukuman bagi pelaku. Hal ini sesuai yang terjadi pada kasus korban AG yang mengalami kekerasan yang merenggut haknya. Ratifikasi hak tersebut membuat hakhak anak yaitu AG memiliki landasan hukum salah satunya di Indonesia. Oleh sebab itu, pelaku yang merupakan ayah, kakak, dan adik korban harus menerima hukuman sesuai pasal hukum yang berlaku di Indonesia.

\section{Keluarga sebagai sistem}

Keluarga merupakan suatu lingkungan terkecil dimana individu bertumbuh. Di dalam kasus kekerasan seksual pada AG ini, keluarga sebagai sistem yang memiliki fungsi-fungsi untuk menerapkan peranannya dan normanorma di dalam keluarga tidak dapat berjalan dengan baik. Minuchin (Wills., 2008) mengungkapkan pandanganya bahwa keluarga merupakan suatu sistem dimana anggota-anggotanya dibatasi oleh nilai dan norma dalam subsistemnya. Norma dan nilai ini berlaku untuk mempertahankan interaksi yang berlangsung baik. Komunikasi dan interaksi akan mempengaruhi persepsi terhadap status dan peran masing-maisng yang akan berpengaruh pula nantinya pada keberfungsian keluarga dan anggotaanggotanya.

Berdasarkan perspektif keluarga sebagai sistem ini maka ketidakberdayaan keluarga dalam menjalankan status dan perannya dan permasalahan dalam interaksi akan mengakibatkan permasalahan dalam sistem keluarga. Di dalam kasus kekerasan seksual ini maka peran Ayah, kakak, dan adik yang melakukan tindakan kekerasan seksual kepada AG megakibatkan terjadi masalah dalam sistem keluarga. Peran pengembangan nilai dan norma di dalam keluarga belum dapat berjalan dengan baik sehingga $A G$ menjadi korban di dalam penyimpangan perilaku yang dimiliki oleh orang tua dan kedua saudara laki-lakinya.

Hal ini seiring dengan konsep yang juga dinyatakan oleh BKKBN (dalam Puspitawati, 2012) bahwa keluarga sebagai unit terkecil dalam masyarakat, keluarga memiliki kewajiban untuk memenuhi kebutuhan-kebutuhan anggota keluarganya yang meliputi kebutuhan fisik seperti memberi makan dan minum, kebutuhan psikologi seperti diberikan kasih sayang, kebutuhan spiritual seperti pemahaman mengenai norma dan nilai, dan sebagainya. Keluarga yang sejahtera digambarkan dapat memenuhi segala kebutuhan anggota keluarga dan dapat selaras dalam tanggung jawab antar peran dalam anggota keluarga.

\section{Dampak Tindakan Kekerasan Seksual bagi Pelaku dan Korban}


Focus: Jurnal

\section{a. Dampak Kekerasan bagi Pelaku}

Dikarenakan tindakannya maka pelaku diputuskan bersalah dan mengalami hukuman penjara untuk perbuatan yang telah dilakukannya. Mereka dipersangkakan dengan Pasal 76D jo Pasal 81 ayat (3) UU RI No 17 Tahun 2016 tentang Perlindungan Anak dan Pasal 8 huruf a jo Pasal 46 UU RI No 23 Tahun 2004 tentang Penghapusan Kekerasan dalam Rumah Tangga atau Pasal 285 KUHP. Adapun pasal yang telah dilanggar yaitu Pasal 81 ayat 3 UU RI No 17 Tahun 2016 tentang Perlindungan Anak, yang mana ayat 3 tersebut adalah orang-orang yang melakukan hubungan persetubuhan yang dilakukan oleh orang-orang terdekat, bisa orang tua, wali, orang-orang yang menetap dalam rumah tangga, kemudian tenaga pendidik dan orangorang yang memiliki hubungan darah. Masa penahanan dapat ditempuh dalam minimal 5 sampai 15 tahun atau lebih. Sedangkan untuk pelaku yang masih dibawah umur yaitu adik korban dihukum melalui mekanisme peradilan anak yang dapat membuatnya dihukum setengah masa penahanan dewasa.

Proses pemberian hukuman yang dilakukan dengan tindakan penahanan ini seperti yang telah dijelaskan akan membuat pelaku anggota keluarga yaitu ayah dan anak ditahan minimal 5 atau lebih. Jangka waktu ini akan membuat pelaku mengalami perubahan dalam diri dan lingkungannya. Menurut Williams (dalam Riza \& Herdiana, 2012) dalam artikel Prison Health and the Health of the Public, situasi ketika awal masuk penjara adalah keadaan yang paling mempengaruhi psikologis narapidana. Kegiatan yang bisa dilakukan sesuka hati seorang individu diluar dapat berubah drastis dalam penjara. Hal ini meliputi segala peraturan ketat dalam penjara yang membuat narapidana tidak dapat bergerak bebas dan akan menimbulkan tahap stress dalam diri narapida. Kekuatan beradaptasi dan pengendalian diri bergantung pada tingkat resiliensi yang dimiliki oleh narapida. Jika Ia memiliki tingkat resiliensi tinggi maka akan mampu beradaptasi dan menganani permasalahan perubahan pola hidup di dalam lapas namun jika tidak akan mengalami permasalahan sosial dan psikologis di dalam lapas. Berdasarkan Riza \& Herdiana (2012) subjek yang memiliki resiliensi tinggi akan memiliki rencana untuk memulai kehidupan barunya ketika menyelesaiakan masa penahanan dengan visi berubah menjadi lebih baik dan mampu melaksanakan semua tugas tanpa beban namun untuk individu yang memiliki tingkat resiliensi rendah akan cenderung stress dan depresi karena tidak menerima keadaan serta tidak dapat beradaptasi dengan lingkungannya yang jika berkelanjutan tingkat stress ini akan mengarah kepada bunuh diri. Oleh karena itu beberapa ahli menganggap proses penahanan bukan suatu jalan keluar terbaik.

Sebagai pelaku tindakan kekerasan seksual, pelaku juga membutuhkan rehabilitasi terkait aspek mental dan sosialnya. Hal ini bertujuan kembali untuk memberikan rekonstruksi pemikiran dan membantu pelaku sehingga dapat siap melakukan keberfungsian sosialnya ketika bebas. Terlebih proses rehabilitasi dibutuhkan jika memang pelaku memiliki penyimpangan seperti yang terjadi pada salah satu pelaku yang merupakan adik kandung korban. Pelaku memerlukan proses rehabilitasi yang mendalam guna memberikan pendampingan penyembuhan mental dan sosialnya.

\section{b. Dampak Kekerasan Bagi Korban}

Korban yang merupakan subjek pelampiasan pelaku sangat mendapatkan pengaruhnya bagi aspek psikologis maupun psikososial dalam dirinya. Meskipun dalam kasus ini, korban merupakan anak berusia 18 tahun namun dikarenakan kondisi keterbelakangan mental yang dialaminya menyebabkan dirinya memiliki pola pemikiran seperti anak-anak dimana masih tidak berdaya dan mudah untuk diancam atau dipengaruhi.

Kekerasan seksual yang dialami oleh korban akan menyebabkan dampak berupa trauma psikososial dan psikologis yang berkepanjangan. Noviana (2015) menyatakan pendapatnya mengenai dampak dari sisi biologis dan sosial. Untuk sisi biologis organorgan vital korban yang dipaksa untuk melakukan tindakan seksual akan mengalami gangguan. Selain itu pada sisi sosial korban akan mudah merasa terintimidasi yang berdmpak pada kekurangan kepercayaan diri korban. Browne dan Finkelhore (dalam Sakalasastra \& Herdiana, 2012) menyatakan dampak yang akan dialami korban dalam beberapa dimensi yaitu dimensi afeksi, kognisi, psikomotor, dan sosial. Pada dimensi afeksi terbentuk emosi negatif yang akan membentuk anak menjadi tidak mudah untuk berempati, pada dimensi kognisi akan membuat anak membuat penilaian yang cenderung negatif pada lingkungan dan 
Focus: Jurnal

Pekerjaan Sosial

sekelilingnya juga berkaitan dirinya sendiri. Sedangkan pada dimensi psikomotor akan mnyebabkan penyimpangan pada perilaku seksual anak, kemudian pada dimensi sosial akan membuat anak buruk dalam tahap sosialisasi karena adanya kecenderungan untuk menutup diri.

Dimensi-dimensi ini jika telah
bermasalah akan mempengaruhi
perkembangan tumbuh kembang anak
seterunya. Terkhusus pada masa anak remaja
dimana pada masa pencaharian jati diri ini
anak yang menjadi korban tindak kekerasan
akan semakin sulit menemukan jati dirinya di
masa krisis ini. Ketidak berhasilan anak dalam
tahap ini berdasarkan Erikson dalam
perkembangan psikososialnya akan
mengakibatkan anak menjadi bingung akan
jatidirinya dan memiliki kecenderungan emosi
dan perilaku negatif (Krismawati, 2014).

Dampak trauma khususnya dalam faktor dimensi psikomotor harus sangat diperhatikan. Hal ini karena berdasarkan berbagai macam faktor penyebab kekerasan pada anak berdasarkan Probosiwi \& Bahransyaf (2015) yang diantaranya mencakup empat penyebab, faktor pewarisan kekerasan pada masa kecil berpengaruh. Hal ini menyebabkan harusnya ada upaya rehabilitasi yang baik dan lebih khusus pada korban karena korban pun memiliki keterbatasan mental sehingga perilaku yang telah terjai tidak membuat korban menjadi mengulanginya bagi orang lain ataupun membentuk korban menjadi pribadi yang berkencenderungan negatif dalam setiap dimensi kehidupannya.

\section{Peran Pekerja Sosial bagi intervensi Kasus}

\section{a. Intervensi Pekerja Sosial Bagi Korban}

Pekerjaan sosial merupakan suatu profesi yang bergerak di bidang pemberian pertolongan. Secara sederhana profesi pekerjaan sosial juga dapat dinyatakan sebagai profesi yang memiliki kewenangan keahlian dalam penyelenggaraan pelayanan sosial (Wibhawa, 2015). Intervensi pekerjaan sosial meliputi segala upaya guna meningkatkan keberfungsian sosial individu, kelompok atau masyarakat.

Peran pekerja sosial cukup luas berkaitan dengan lingkup individu, kelompok, dan masyarakat. Di dalam perannya dalam kekerasan terhadap anak, pekerja sosial berperan dalam case management dan pelaksana treatment. Faller (dalam Rusyidi \& Raharjo, 2018) menjelaskan bahwa berkaitan dengan kasus kekerasan terhadap anak, pekerja sosial dapat bekerjasama dengan berbagai profesi seperti psikolog, psikiater, dokter, ahli-ahli hukum dan sebagainya untuk dapat memberikan perlindungan dan keselamatan bagi korban. Kerjasama multi disiplin ilmu ini dilakukan guna memberikan rasa aman dan memperbaiki keberfungsian sosial anak yang telah terlanggar hak-haknya.

Sedangkan dalam menyediakan treatment, pekerja sosial dapat melaksanakan proses pendampingan psikososial yang membantu anak menyembuhkan trauma psikisnya dalam segi sosial. Dalam hal ini anak diberikan keterampilan dan pengajaran untuk mengatur emosi, diberikan pendampingan dan dukungan sosial serta dilakukan monitoring dan evaluasi secara berkala.

Di dalam peranannya untuk melaksanakan pendampingan psikososial, Pekerja sosial menerapkan prinsip-prinsipnya meliputi accepatance, individualization, non judmentalism, objectivity, dan self determination. Dengan prinsip-prinsip ini pekerja sosial malakukan proses pendampingannya. Adapun proses pendampingannya meliputi:

1. melakukan pendekatan awal (intake) yang meliputi kontak dan pendekatan pada klien yang merupakan korban.

2. Tahapan selanjutnya berkaitan dengan assessment dimana pekerja sosial memahami masalah klien dengan mendengarkan keluhan, kekhawatiran ataupun kesulitan yang dialaminya.

3. Membuat rencana pendampingan atau plan of treatment yang dapat membantu anak merancang sendiri langkah-langkah pemecahan masalah yang dialami yang berkaitan dengan pemulihan psikologisnya.

4. Melakukan pendampingan diantaranya seperti yang telah disebutkan sebelumnya yaitu pemberian motivasi atau dukungan, pemberian terapiterapi untuk pengaturan emosi, bekerjasama dengan berbagai multidisiplin ilmu untuk memberikan 
Focus: Jurnal Pekerjaan Sosial
ISSN: $2620-3367$
Vol. 2 No: 2
Hal: $198-207$

Desember 2019 akses pada kebutuhan anak dan proses pendampingan lainnya.

Fungsi advokasi dan referal juga harus dapat dimiliki oleh pekerja sosial dalam hal membantu permasalahan korban. Fungsi ini dilakukan untuk dapat menyambungkan korban dengan sumber-sumber yang mampu memberikan pertolongan sehingga korban merasa aman dan terlindungi (Rusyidi \& Raharjo, 2018). Kebutuhan-kebutuhan ini seperti kebutuhan akan layanan kesehatan, hukum atau layanan lainnya. Pekerja sosial harus mampu memastikan layanan-layanan tersebut dapat diperoleh oleh korban.

Akan tetapi fungsi-fungsi dan ruang ligkup pekerjaan sosial professional terkait pada sistem politik dan sosial pada masingmasing negara. Berdasarkan Rusyidi \& Santoso (2018) pekerjaan sosial di Indonesia khususnya dalam intervensi dalam kasus kekerasan berperan sebagai pendamping yang berada di rumah aman atau lembaga peradilan. Pekerja sosial juga dapat berfungsi sebagai konselor dan pelaksana rehabiitasi psikologi dan perilaku yang tetap berafiliasi dengan institusi atau masyarakat. Peran advokasi juga sudah terlihat dengan pekerja sosial berada pada banyak lembaga-lembaga sosial yang menyalurkan sumber-sumber bantuan pada korban-korban tindak kekerasan.

\section{b. Intervensi Pekerja Sosial Bagi Pelaku}

Banyak ahli sepakat bahwa harus dapat dilakukan intervensi pula dari kedua belah pihak yang terlibat dalam kejahatan. Tidak hanya pada korban namun juga pada pelaku sehingga kejahatan serupa dapat lebih ditanggulangi dengan lebih baik lagi (Feller, dalam Rusyidi \& Santoso, 2018).

Oleh karena hal tersebut maka pekerja sosial dapat melaksanakan treatment bagi pelaku. Khususnya pada kasus kekerasan seksual yang dilakukan oleh pelaku maka pekerja sosial bekerjasama dengan ahli psikologi untuk dapat menangani pelaku secara psikis dan sosial. Dalam cakupan sosial, pekerja sosial memberikan treatment untuk rehabilitasi sosial yang memulihkan proses sosial melalui interaksi dan memulihkan rekonstruksi sosial yang berada pada faktor kognitif pelaku dengan proses treatment bertahap yang dilakukan pekerjaan sosial.
Selain intervensi pada kedua belah pihak, intervensi yang berkaitan dengan sosialisasi dan pencegahan juga harus coba dilakukan oleh berbagai pihak termasuk pekerja sosial yang dapat menjadi motor pencegahan. Pekerja sosial yang bekerja dalam institusi strategis dapat diberikan kewenangan untuk memonitoring dan melakukan edukasi pada masyarakat untuk mencegah terjadinya kekerasan pada anak dalam segala bentuk apapun.

\section{PENUTUP}

Kekerasan terhadap anak yang masih marak terjadi harus segera diberikan perhatian yang serius. Terkhusus kekerasan banyak dilakukan oleh orang terdekat korban. Proses pencegahan perlu dilakukan dengan sosialisasi dan monitoring berbagai pihak di dalam masyarakat.

Peningkatan penanganan antara korban dan pelaku juga perlu diperhatikan. Kolaborasi berbagai pihak termasuk pekerjaan sosial khususnya di Indonesia dapat lebih ditingkatkan karena pekerja sosial dapat sangat bersinggungan langsung dengan ruang lingkup ini. Proses kolaborasi berbagai multidisiplin ilmu akan lebih memberikan hasil terbaik pemberian kesejahteraan bagi anak dan pemberian hasil yang baik dalam proses rehabilitasi pelaku.

\section{DAFTAR PUSTAKA}

Ayah dan Anak Pelaku Inses di Lampung Terancam 15 Tahun Bui. (2019, Februari 25). Retrieved from CNN Indonesia: https://www.cnnindonesia.com/nasion al/20190225075836-12-372279/ayahdan-anak-pelaku-inses-di-lampungterancam-15-tahun-bui

Fitri, A. N., Riana, A. W., \& Fedryansyah, M. (2015). PERLINDUNGAN HAK-HAK ANAK DALAM UPAYA PENINGKATAN KESEJAHTERAAN ANAK . PROSIDING KS: RISET \& PKM , 46-47.

Komnas Perempuan. (2019, Maret ). Lembar Fakta dan Poin Kunci Catatan Tahunan Komnas Perempuan Tahun 2019.

Krismawati, Y. (2014). Teori Psikologi Perkembangan Erik H. Erikson dan Manfaatnya Bagi Tugas Pendidikan Kristen Dewasa Ini. Jurnal Teologi dan Pendidikan Agama Kristen, 46-56. 


\begin{tabular}{|c|c|c|c|c|}
\hline $\begin{array}{c}\text { Focus: Jurnal } \\
\text { Pekerjaan Sosial }\end{array}$ & ISSN: $2620-3367$ & Vol. 2 No: 2 & Hal: $198-207$ & Desember 2019 \\
\hline
\end{tabular}

Noviana, I. (2015). KEKERASAN SEKSUAL TERHADAP ANAK: DAMPAK DAN PENANGANANNYA. Sosio Informa, 1328.

Prayogo, S. (2016). PERILAKU MENYONTEK DALAM KAJIAN TEORI KOGNITIF SOSIAL ALBERT

BANDURA (Studi Pada Siswa Kelas XI SMA Negeri 1 Tegineneng, Kecamatan Tegineneng,

Kabupaten Pesawaran Tahun Ajaran 2015/2016). Tesis. Lampung: Universitas Lampung.

Probosiwi, R., \& Bahransyaf, D. (2015). PEDOFILIA DAN KEKERASAN SEKSUAL: MASALAH DAN PERLINDUNGAN TERHADAP ANAK. Sosio Informa , 29-40.

Puspitawati, H. (2012). Gender dan Keluarga: Konsep dan Realita di Indonesia. . Bogor: PT IPB Press.

Rakhmad, W. N. (2016). KEKERASAN TERHADAP ANAK DALAM KONSTRUKSI KORAN TEMPO . Jurnal IImu Sosial, 53-62.

Riza, M., \& Herdiana, I. (2012). Resiliensi pada Narapidana Laki-laki di Lapas Klas 1
Medaeng. Jurnal Psikologi Kepribadian dan Sosial, 142-147.

Rusyidi, B., \& Raharjo, S. T. (2018). PERAN PEKERJA SOSIAL DALAM PENANGANAN KEKERASAN TERHADAP PEREMPUAN DAN ANAK. SOSIO Informa, 375-387.

Sakalasastra, P. P., \& Herdiana, I. (2012). Dampak Psikososial Pada Anak Jalanan Korban Pelecehan Seksual Yang Tinggal di Liponsos Anak Surabaya. Jurnal Psikologi Kepribadian dan Sosial, 68-73.

Tursilarini, T. Y. (2016). Inses: Kekerasan Seksual dalam Rumahtangga terhadap Anak Perempuan. Jurnal PKS, 165178.

Wibhawa, B. R. (2015). Pengantar Pekerjaan Sosial. Bandung: Unpad Press.

Wills., H. S. (2008). Konseling Keluarga. Bandung: Alfabeta. 